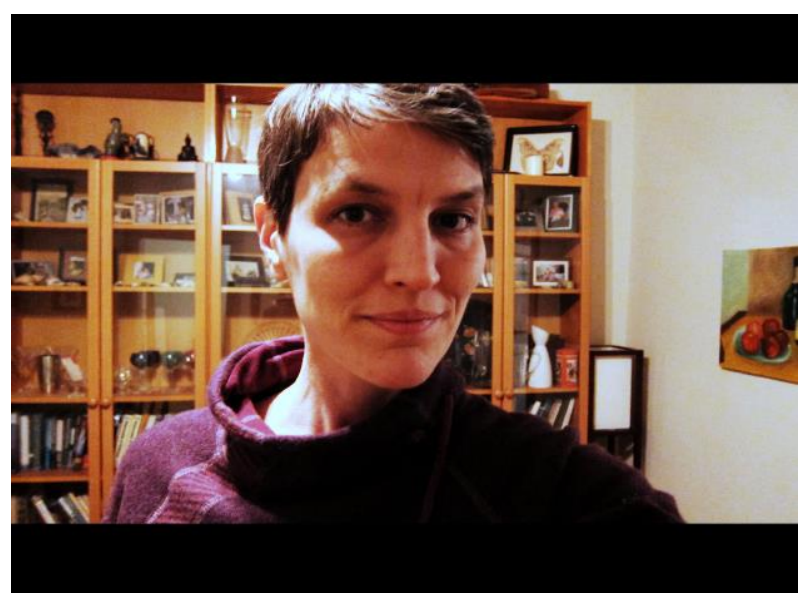

\title{
Profile: Genevieve Gore
}

\author{
Liaison Librarian \\ McGill University \\ Montreal, Quebec
}

\section{Describe your early background:}

I grew up in Montreal, in NDG (NotreDame-de-Grâce) to be specific. I went to a private French school for girls in one of the posher areas of the island and always felt

like an underdog there. Thankfully, my family helped me develop a good sense of humour, and that has allowed me to deal with just about anything.

\section{What (or who) influenced you to pursue a career in libraries?}

I must have been impressed with libraries from an early age. When I was little, I collected all the kids' books in our house, stuck call numbers on them (my own classification system - I can't figure it out now), and loaned them to my siblings. I don't know if I fined them late fees or not.

I considered librarianship when I was an undergrad but dropped the idea because I thought l'd be poor. I was a research assistant in a paediatric hospital for a little while and really enjoyed the searching part of the job (in fact, I wanted to "fix" MEDLINE, mostly because I didn't understand how it worked). My Mom suggested librarianship to me in my late 20s, and it seemed like fate although I was really sold on the idea after chatting with the Director of Libraries at McGill, Frances Groen. In retrospect, I really appreciate that Fran took the time to sit down with me like that. It was really generous of her.

\section{Where are you working now, and what do you like best about your current job?}

I work at McGill University now, and I enjoy my job because of the people and the intellectually challenging work. My colleagues are fantastic-smart and fun, a great combination, and the students, faculty and staff are really pleasant and intelligent. I actually like going to work in the morning - well, maybe not always, but definitely most of the time. 


\section{What do you do for recreation?}

I love to walk. People make fun of me for it. I walk faster than they do, usually, although I did waddle when I was pregnant. I did not enjoy waddling.

What accomplishment are you most proud of?

My two kids! They are the best thing that ever happened to me.

What issues do you think will have a big impact on libraries in the next few years?

Trying to retain the "Library as place" within universities as we compete with other university "places" where students have the same virtual access to our collections.

If you had one chance to time travel, when would you travel to and why?

I'd travel back to when my Mom was alive, to one of our rambunctious family dinners.

Is there anything else you'd like to mention that might interest Partnership readers?

Librarians are awesome, spread the word! 